Journal of Applied Pharmaceutical Science Vol. 2 (9), pp. 045-049, September, 2012

Available online at http://www.japsonline.com

DOI: $10.7324 /$ JAPS.2012.2909

ISSN 2231-3354 (cc) BY-NC-SA

\title{
Spasmodic Responseand Neurogenic Mechanism of Water Extract of Vernonia dinerea (L.) Less on Rat Duodenum
}

\author{
Ganesh Panday $^{\mathrm{a}-\mathrm{b}}$, V.K Kasana ${ }^{\mathrm{b}}$, S.K Hore ${ }^{\mathrm{c}}$, S.K.Hore ${ }^{\mathrm{c}}$ \\ ${ }^{a}$ Deparment of Chemistry, Graphic Era Parvatiya Vishwavidyalaya, Bhimtal, Nainital, Uttarakhand, India. \\ ${ }^{b}$ Department of Chemistry, College of Basic Science \& Humanities, G.B. Pant University of Agriculture Technology, Pantnagar-263145,Udham Singh \\ Nagar, Uttarakhand, India. \\ ${ }^{\mathrm{c}}$ Department of Pharmacology \& Toxicology, College of Veterinary \& Animal Sciences ,G.B .Pant University of Agriculture \& Technology, Pantnagar- \\ 263145,Udham Singh Nagar, Uttarakhand, India.
}

\section{ARTICLE INFO}

Article history:

Received on: $1 / 10 / 2011$

Revised on: 20/12/2011

Accepted on: 03/01/2012

Available online: $28 / 09 / 2012$

Key words: Vernonia cinerea, Rat duodenum; Aqueous

extract; Spasmodic response

\begin{abstract}
Use of different agonists and antagonists for elucidating the mechanism of aqueous extract of Vernonia cinerea (L.) Less. on duodenal smooth muscle of female albino rat suggested the presence of an active ingredient in plant having spasmogenic response that has neurogenic mechanism on rat duodenal smooth muscle. The responses of extract were dose dependent and fully reversible on wash. The findings suggested that the extract responses mediate through agonistic action without blockade of any receptor enzyme. Extract possibly stimulates presynaptic cholinergic nerve endings to produce spasmodic response in rat duodenal smooth muscle.
\end{abstract}

\section{INTRODUCTION}

In continuation to our studies on essential oils and extracts of medicinal plants and their pharmacological study (Prakash et al, 2006), we investigated spasmodic response and neurogenic mechanism of action of water extract of Vernonia cinerea ( L.) Less on contractility of rat duodenal smooth muscle. The whole plant of V.cinerea has been documented to exhibit significant diuretic activity(Herrera et al,1998), anti-inflammatory

* Corresponding Author

E-mail: gp1427@gmail.com

Tele No. +91-8881225493, Fax: +915944-233473
Activity (Mazumder et al, 2003), antipyretic potential and antibacterial activity (Malaya et al, 2003b, a). Leaves showed diuretic and anti-diuretic activity (Adeboye et al, 1997) analgesic, antipyretic and anti- inflammatory activities (Iwalewa et al, 2003). Plant Vernonia cinerea (Sahadevi) belonging to genera Vernonia, is used as a folk medicine by the people of Nepal (Hu et al, 2004). The plant is found in tropical Asia, Africa, Australia and New Zealand. In India it is found throught the country, ascending upto $2400 \mathrm{~m}$ in the Himalaya, Khasi hills and hills of peninsular India and is very common weed of the roadsides, garden lands and open forest. 


\section{MATERIAL AND METHODS}

\section{Plant material}

Fresh plants of $V$. cinerea were collected locally from Tarai region of Himalaya, Pantnagar( Uttarakhand), India. The specimen has been deposited in the Department of Chemistry, G.B. Pant University of Agriculture \& Technology, Pantnagar, India.

\section{Animals}

The Pharmacological study was conducted on adult female albino rats (175-225g), purchased from Laboratory Animal Resource Section, Indian Veterinary Research Institute, Izatnagar, Uttar Pradesh, India. The rats were maintained in Polypropylene cages and housed in the animal sheds of Department of Pharmacology and Toxicology College of Veterinary \& Animal Sciences, G.B .Pant University of Agriculture \& Technology, Pantnagar Uttarakhand, India under good managemental conditions. Animals were fed standard ration ad libitum and had free access to clean drinking water.

\section{Isolation of water extract}

Fresh plants of $V$. cinerea $(5 \mathrm{~kg})$ were collected from its natural habitat in the month of May and were shade dried for about 30 days. Shade dried plant material was powdered. For the purpose of extraction, about $1 \mathrm{~kg}$ powdered plant material was dipped in triple distilled water for 20 days and stirring was done after every 4 to 5 days. The infusion was filtered through muslin cloth. The crude aqueous extract of plant was obtained after evaporation of water under reduced pressure.

\section{Tissue preparation and mounting}

Female albino rats weighing between $175-225 \mathrm{~g}$ body wt. were anaesthetized with pentobarbitone sodium (40 mg/kg, IP) and sacrificed by cervical dislocation and exaguination .A small piece ( $3 \mathrm{~cm}$ long) of duodenum $4 \mathrm{~cm}$ apart stomach was removed, cleaned and mounted on an organ bath containing Tyrode solution (composition in $\mathrm{mM}: \mathrm{NaCl} \quad 137, \mathrm{KCl} \quad 2.7, \mathrm{CaCl}_{2} \quad 1.8, \mathrm{MgCl}_{2}$ $0.2, \mathrm{NaHCO}_{3} \quad 11.9, \mathrm{NaHPO}_{4} \quad 0.4$ and glucose 5.5,pH 7.4). The bathing fluid was continuously bubbled with air and maintained at constant temperature $\left(37 \pm 0.5^{\circ} \mathrm{C}\right)$. The tissue was allowed to equilibrate for a period of $30 \mathrm{~min}$ under a resting tension of $0.5 \mathrm{~g}$. During this period the tissue was washed every $15 \mathrm{~min}$.

After equilibration, drugs were administered in bath fluid to record their effect on physiograph (Bio-devices, India).Every time responses of 2 successive doses of acetylcholine (ACh), at an interval of $10 \mathrm{~min}$ were recorded to confirm optimum responsiveness of the tissues.

\section{Drugs}

Serial solutions of water extract of $V$. Cinerea whole plant (VWE) were prepared directly in Tyrode solution and mixed properly with the help of an Ultra-Sonicator (Soni prep 150,UK). The solutions were sonicated before use.

\subsection{Effect of VWE on basal tone of rat duodenum}

Effect of cumulative doses $(0.25$ to $25 \mathrm{mg} / \mathrm{ml})$ of VWE on rat duodenal smooth muscle was recorded. To elucidate the mechanism of action of VWE, different agonists and antagonists were used as per the following steps-

1. Each tissue preparation was exposed to only one agonist or one combination.

2. Dose dependent contractions induced by VWE ( 0.25 to $25 \mathrm{mg} /$ $\mathrm{ml})$ were recorded.

3. Atropine sulphate $(1 \mu \mathrm{g} / \mathrm{ml})$ was added to the bath fluid $15 \mathrm{~min}$ before recording the response of VWE $(10 \mathrm{mg} / \mathrm{ml})$ and $\mathrm{ACh}(2$ $\mathrm{ng} / \mathrm{ml}$ ) to antagonise their effects.

4. The independent and combined effects of VWE $(10 \mathrm{mg} / \mathrm{ml})$ \& ACh $(2 \mathrm{ng} / \mathrm{ml})$ were observed.

5. The response of $\mathrm{ACh}(2 \mathrm{ng} / \mathrm{ml})$ was recorded in presence of low dose VWE (1 $\mathrm{mg} / \mathrm{ml}, 15 \mathrm{~min}$.), which produced fible contractile response in rat duodenum.

6. The response of VWE $(10 \mathrm{mg} / \mathrm{ml})$ and $\mathrm{ACh}(2 \mathrm{ng} / \mathrm{ml})$ were taken before and after incubating the tissue with lignocaine hydrochloride $(50 \mu \mathrm{g} / \mathrm{ml})$ for $5 \mathrm{~min}$.

7. The ACh $(2 \mathrm{ng} / \mathrm{ml})$ and VWE $(10 \mathrm{mg} / \mathrm{ml})$-induced contractions were recorded in absence and presence of fresh rat serum (40 $\mu \mathrm{l} / \mathrm{ml}, 5 \mathrm{~min}$.).

8. Experiments were also conducted on the preparations that had been started at low temperature of $4^{\circ} \mathrm{C}$ for $96 \mathrm{~h}$ for enervation, but were later maintained at $37^{\circ} \mathrm{C}$ bath temperature during experiment.

\section{Statistical analysis}

The results are presented as mean \pm S.E. of $n$ observations. Values were analyzed using a student's t-test or ANOVA an appropriate and were considered to differ significantly when $\mathrm{p} \leq 0.05$.

\section{RESULTS AND DISCUSSION}

VWE produced dose dependent contractile responses on rat isolated duodenum (Table I \& II, Fig. 1\&2). This response indicated that the plant contained an active ingredient, which has spasmogenic response on rat duodenal smooth muscle. The responses of VWE been fully reversible on wash. This finding suggests that VWE's responses were mediated through an agonistic action without blockade of any receptor or enzyme. Acetylcholine (2 $\mathrm{ng} / \mathrm{ml})$ and VWE $(10 \mathrm{mg} / \mathrm{ml})$ produced contractile response on isolated rat duodenum by $1.178 \pm 0.16$ and $1.086 \pm 0.08 \mathrm{~g}$, respectively. In presence of atropine $(1 \mu \mathrm{g} / \mathrm{ml})$, the contractile effects of ACh $(2 \mathrm{ng} / \mathrm{ml})$ and VWE $(10 \mathrm{mg} / \mathrm{ml})$ were blocked completely (Fig. 3). Atropine is a muscarinic cholinergic receptor blocker.Hence, inhibition of contractile responses of $\mathrm{ACh}$ and VWE by atropine indicates that the responses of these two agonists were mediated through muscarinic receptors. There seems to be one or more than one of the three possible mechanisms responsible for this contractile action of VWE- (i) stimulation of $\mathrm{ACh}$ release from the cholinergic nerve endings, (ii) 
inhibition of acetylcholinesterase enzyme at the neuroeffector junction, or (iii) direct activation of the muscarinic receptors of rat duodenal smooth muscle (Hore et al, 1999). The combination of $\mathrm{ACh}$ and an anticholinesterase agent produces a potentiated effect (Kela et al, 1995), because the fraction of ACh molecules, which is normally destroyed by acetylcholinesterase enzyme in absence of anticholinesterase, becomes available to act on the receptors to produce extra effect.

Table. 1 Dose dependent contractile responses $(\mathrm{mm})$ of VWE on rat duodenum $(n=6)$.

\begin{tabular}{cccccccc}
\hline $\begin{array}{c}\text { Dose of VWE } \\
(\mathbf{m g} / \mathbf{m l})\end{array}$ & $\mathbf{1}$ & $\mathbf{2}$ & $\mathbf{3}$ & $\mathbf{4}$ & $\mathbf{5}$ & $\mathbf{6}$ & $\begin{array}{c}\text { Mean } \pm \text { SE } \\
(\mathbf{m m})\end{array}$ \\
\cline { 2 - 7 } & 3 & 4 & 2 & 3 & 3 & 2 & $2.83 \pm 0.31$ \\
0.25 & 7 & 12 & 4 & 6 & 8 & 4 & $6.83 \pm 1.22$ \\
0.75 & 9 & 15 & 13 & 9 & 15 & 11 & $12.00 \pm 1.13$ \\
2.50 & 17 & 22 & 18 & 13 & 24 & 16 & $18.33 \pm 1.65$ \\
7.50 & 33 & 29 & 23 & 18 & 29 & 22 & $25.67 \pm 2.28$ \\
25.00 & & &
\end{tabular}

Table. 2 Dose dependent contractile responses (g) of VWE on rat duodenum $(n=6)$.

\begin{tabular}{cccccccc}
\hline $\begin{array}{c}\text { Dose of } \\
\text { VWE } \\
(\mathrm{mg} / \mathrm{ml})\end{array}$ & 1 & 2 & 3 & 4 & 5 & 6 & \multirow{2}{*}{$\begin{array}{c}\text { Mean } \pm \mathrm{SE} \\
(\mathrm{g})\end{array}$} \\
\cline { 2 - 7 } & 0.15 & 0.20 & 0.10 & 0.15 & 0.15 & 0.15 & $0.14 \pm 0.02$ \\
0.25 & 0.35 & 0.60 & 0.20 & 0.30 & 0.40 & 0.20 & $0.34 \pm 0.06$ \\
0.75 & 0.45 & 0.75 & 0.65 & 0.45 & 0.75 & 0.55 & $0.60 \pm 0.06$ \\
2.50 & 0.85 & 1.10 & 0.90 & 0.65 & 1.20 & 0.80 & $0.92 \pm 0.08$ \\
7.50 & 1.65 & 1.45 & 1.15 & 0.90 & 1.45 & 1.10 & $1.28 \pm 0.11$ \\
25.00 & & & & & & & \\
\hline
\end{tabular}

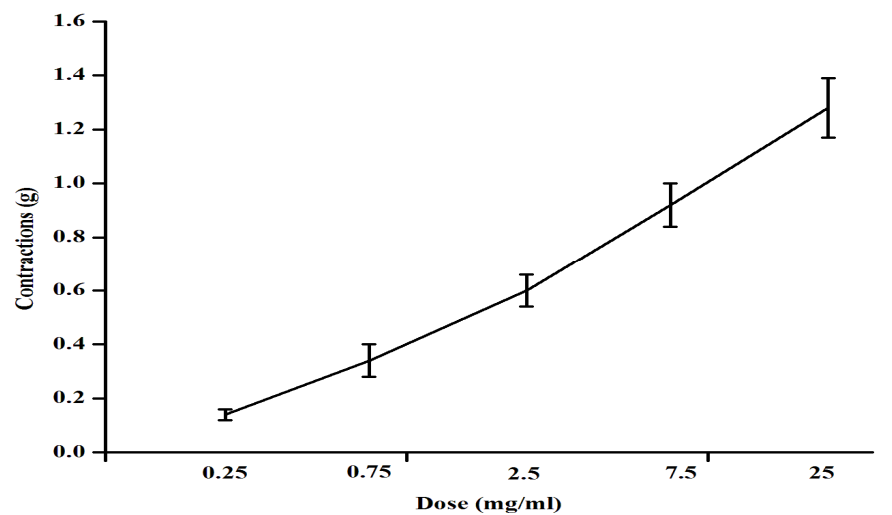

Fig.1 : Cumulative dose- dependent Contractile responses of aqueous extract of Vernonia cinerea whole plant on rat duodenum( $(n=6)$.

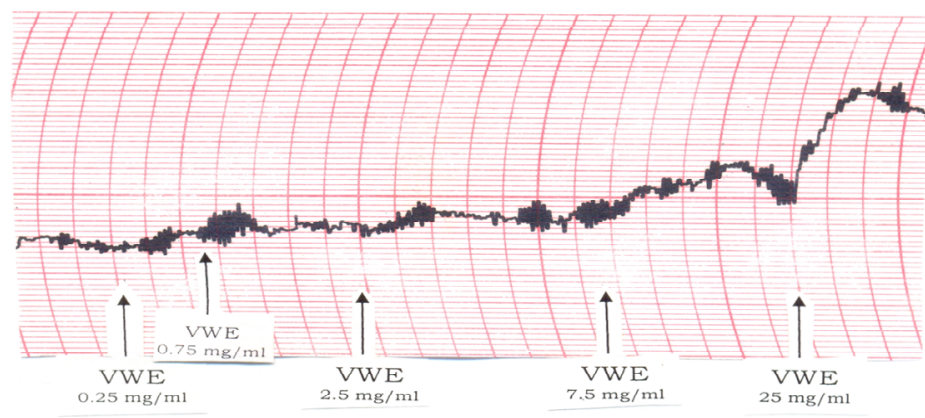

Fig. 2: Cumulative dose dependent responses of VWE on isolated rat duodenal smooth muscles.

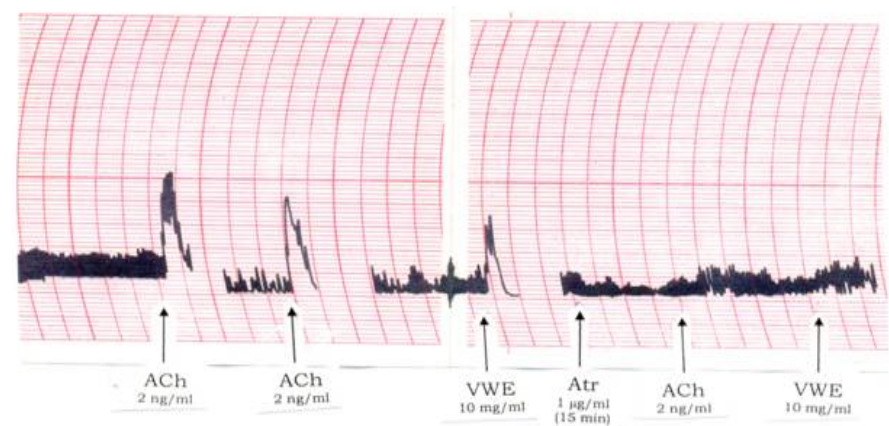

Fig. 3: Effect of atropine (atr) on Ach and VWE-induced contraction in rat duodenum.

This finding supports the neurogenic mechanism of VWE-mediated response in rat duodenum. Here, VWE stimulated the presynaptic cholinergic nerve endings to release Ach, which was responsible for the contractile response. The cholinesterase enzymes of serum or plasma hydrolysed the ACh and thereby abolished the response of VWE. The non-responsiveness of VWE in presence of serum or plasma (AChE) also suggests that VWE did not directly stimulate the cholinergic receptors. In the present study, VWE did not potentiate the responses of ACh (Fig. 4) . The combination of ACh $(2 \mathrm{ng} / \mathrm{ml})$ and VWE $(10 \mathrm{mg} / \mathrm{ml})$ produced additive response $(2.00 \pm 0.159 \mathrm{~g})$. The contractile response of $\mathrm{ACh}(2 \mathrm{ng} / \mathrm{ml})$ remained unaltered in tissue preparations previously incubated with low dose of VWE $(1 \mathrm{mg} / \mathrm{ml}, 15 \mathrm{~min})$ (Fig. 5).
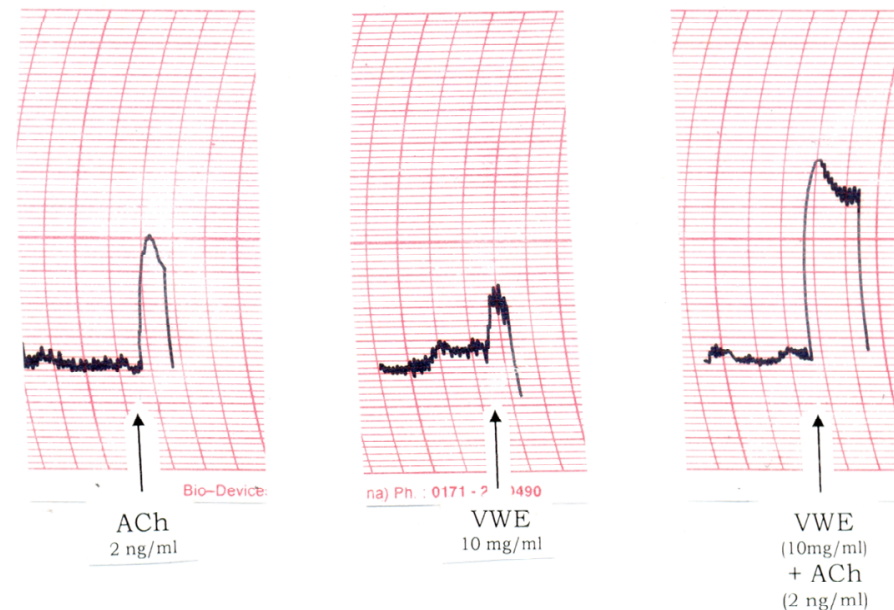

Fig. 4: Independent and combined effects of Ach and VWE on basal tone of rat duodenal smooth muscles.

Hence, this can be assumed that VWE did not inhibit the acetylcholinesterase enzyme. These findings thereby nullify the probable involvement of acetylcholinesterase enzyme in VWEinduced contraction in rat duodenum. Lignocaine, a membrane stabilizer, blocks the axonal conduction and thereby neurotransmitter release in smooth muscles at a concentration of $50 \mu \mathrm{g} / \mathrm{ml}$ ( Mishra and Raviprakash,1980). In our study, the same dose of lignocaine blocked the contractile response of VWE (10 $\mathrm{mg} / \mathrm{ml}$ ). However, the ACh (2 ng/ml)-induced contraction 
remained unaltered in presence of lignocaine (Fig. 6). Therefore, it is an indirect evidence that there was possible stimulation of ACh release at the prejunctional site by VWE. This view is further strengthened by the finding that the contractile response of VWE $(10 \mathrm{mg} / \mathrm{ml})$, but not ACh $(2 \mathrm{ng} / \mathrm{ml})$ was reduced in cooled $\left(4^{\circ} \mathrm{C}\right.$ for $96 \mathrm{~h}$ ) rat duodenal preparations (Fig. 7). The methods of cooling provide a means of obtaining smooth muscle preparation free from the neuronal influences. Hence, the VWE - medicated contraction in present study was seemed to be a neurogenic response.
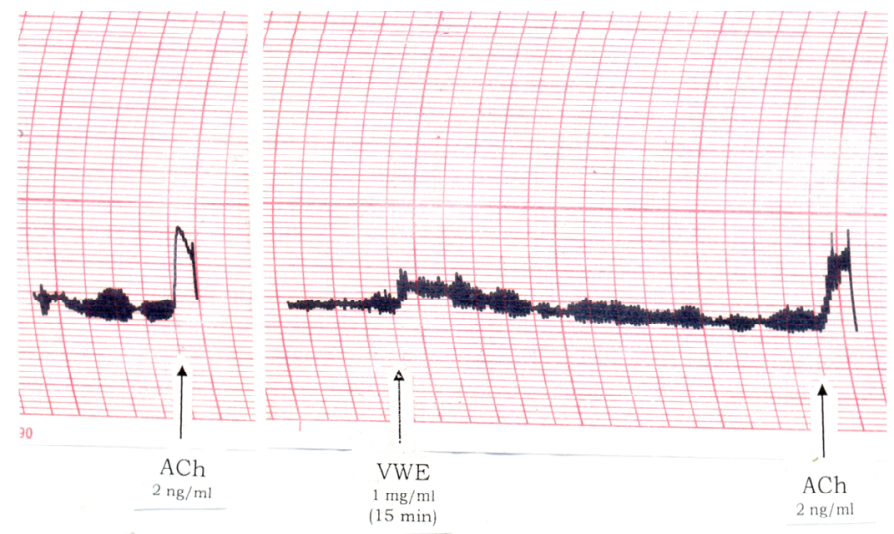

Fig. 5: Response of Ach in absence and presence of extract on rat duodenum.

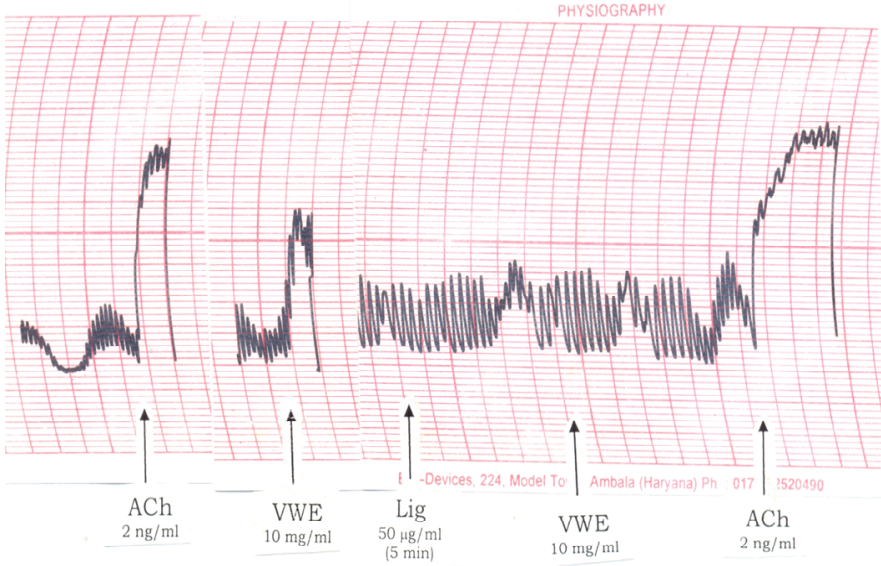

Fig. 6: Responses of VWE and Ach on rat duodena smooth muscle before and after incubating the tissue with lignocaine hyfrochloride (Lig.).

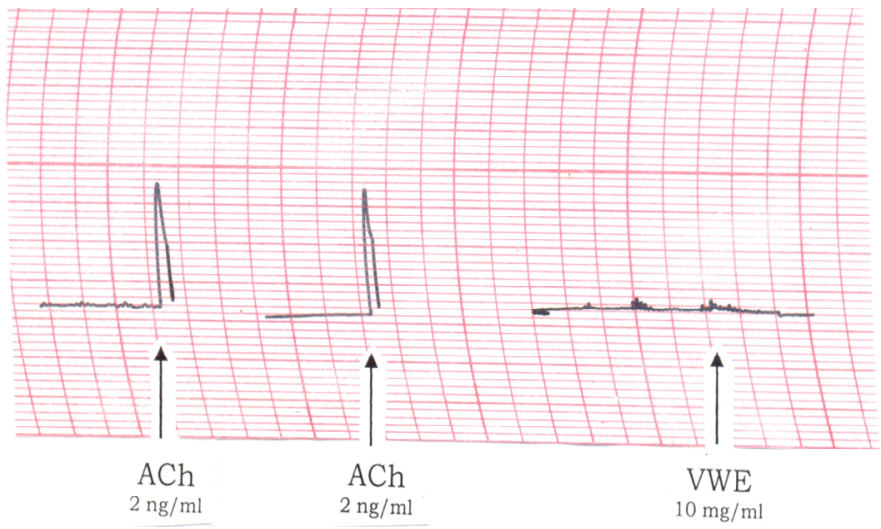

Fig. 7: Responses of Ach and VWE in rat duodenum that had been stored at low temperature of $40^{0 \mathrm{c}}$ for $96 \mathrm{~h}$ for denervation but later maintained at $370 \mathrm{c}$ bath temperature during experiment.
Rat serum or plasma, which contains cholinesterase enzymes responsible for hydrolysing $\mathrm{ACh}$, abolished VWE (10 $\mathrm{mg} / \mathrm{ml})$ and $\mathrm{ACh}$ (2 $\mathrm{ng} / \mathrm{ml})$-induced contractions in rat duodenum(fig. 8 \& 9).

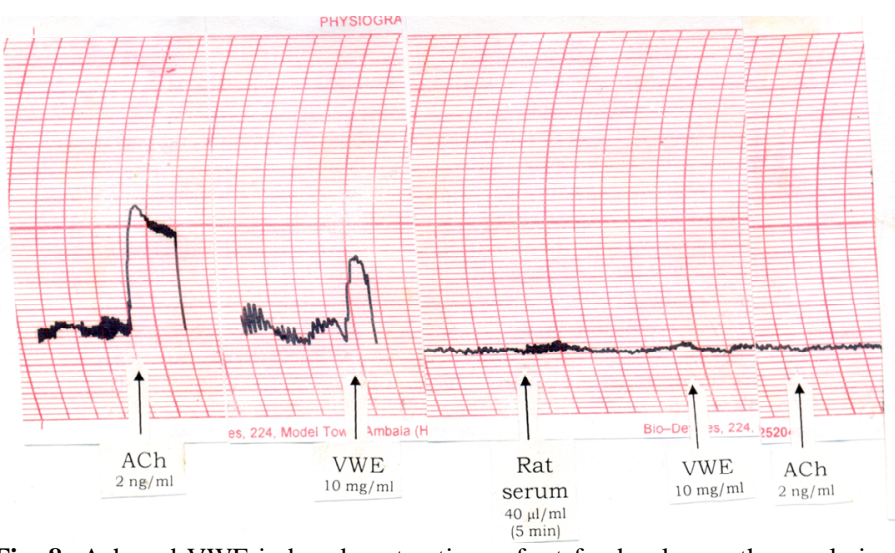

Fig. 8: Ach and VWE-induced contractions of rat fuodenal smooth muscle in absence and presence of rat serum.
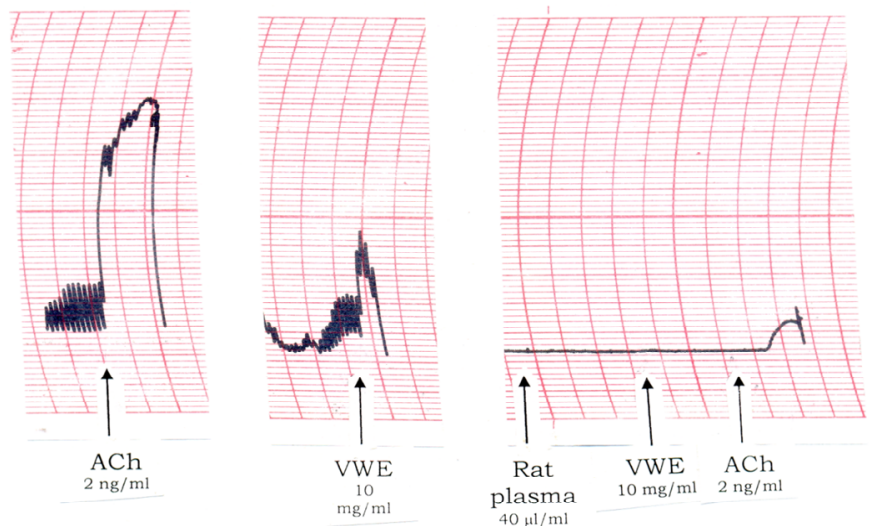

Fig. 9: Ach and VWE-infuced contractons rat duorenum in absence and presence of rat plasma.

In conclusions, it is suggested that VWE possibly stimulates presynaptic cholinergic nerve endings to produce spasmodic response in rat duodenal smooth muscle.

\section{ACKNOWLEDGEMENTS}

Thanks are due to authorities of G.B. Pant University of Agriculture \& Technology ,Pantnagar, India, for providing necessary research facilities.

\section{REFERENCES}

A. K. Kela, A. K. Sharma, V. L. Mehta, Does ethanol release Acetylcholine to produce contraction on isolated Frog rectus abdominis, Indian Journal of Pharmacology. 27(1995) 195-196

C.L. Herrera, F.M. Sison, Y.C. Paras, L.A. Dayap, I. L. Banal, Diuretic principles/compounds from Vernonia cinerea (L.) Less, Philippine-Journal-of-Science (Philippines). 127(2) (1998) 93-102

E.O. Iwalewa O.J. Iwalewa J.O. Adeboye, Analgesic, antipyretic, anti-inflammatory effects of methanol, chloroform and ether extracts of Vernonia cinerea Less leaf, Journal of Ethnopharmacology. 86 (2-3) (2003) 229-234 
G. Malaya, U.K. Mazumder, L. Manikandan, S.Bhattacharya, P.K. Haldar, S. Roy, Evaluation of antipyretic potential of Vernonia cinerea extract in rats, Phytotherapy-Research. 17(7)( 2003a) 804-806.

G. Malaya, U.K. Mazumder, L. Manikandan, P.K. Haldar, S. Bhattacharya, C.C. Kandar, Antibacterial activity of Vernonia cinerea, Fitoterapia. 74(1/2) (2003b) 148-150.

J.O. Adeboye, W. Asije, S.O. Awe, Diuretic and antidiuretic activity of the leaf extracts of Vernonia cinerea (Less) (Fam. Compositae), Phytotherapy Research (United Kingdom).11(6) (1997) 454-456.

M.F. Hu, M.H .Yen, J.W. Liao, K.L. Liu, Hepatoprotective effects of the folk medicines of "Yan-Kan-Tang No. 1" and "Yan-KanTang No.2" on rats,Crop-Environment-and-Bioinformatics. 1(4) (2004) 229-238.

O. Prakash, V. K. Kasana, A. K. Pant, A. Zafar, S. K. Hore, C. S. Mathela, Phytochemical composition of essential oil from seeds of Zingiber roseum Rosc. and its antispasmodic activity in rat duodenum, Journal of Ethnopharmacology.106(2006)344-347
S. K. Hore, R. Ottalwar, K. M. Koley, A. K. Pathak, Possible involvement of cholinergic and adrenergic mechanism in changing contractility of guinea pig ileum by Ipomoea Carnea, Journal of Ethnopharmacology. 71 (1999) 253-259

S. K. Mishra, V. Raviprakash, Possible involvement of a cholinergic mechanism in calcium-induced contractions of chick oesophagus, Journal of Pharmacy Pharmacolog. 32(1980) 716-717

U.K. Mazumder, M. Gupta, L. Manikandan, S. Bhattacharya, P.K. Haldar, S. Roy, Evaluation of anti-inflammatory activity of Vernonia cinerea Less. extract in rats, Phytomedicine. 10 (2-3) (2003) 185-188

\section{How to cite this article:}

Ganesh Panday, S.K.Hore, V.K.Kasana. Spasmodic Response and Neurogenic Mechanism of Water Extract of Vernonia cinerea (L.) Less on Rat Duodenum. J App Pharm Sci. 2012; 2(9): 045-049. 